Edutech, Tahun 12, Vol.1, No.3, Oktober 2013

\title{
MENJADI GURU PROFESIONAL (ISU DAN TANTANGAN MASA DEPAN)
}

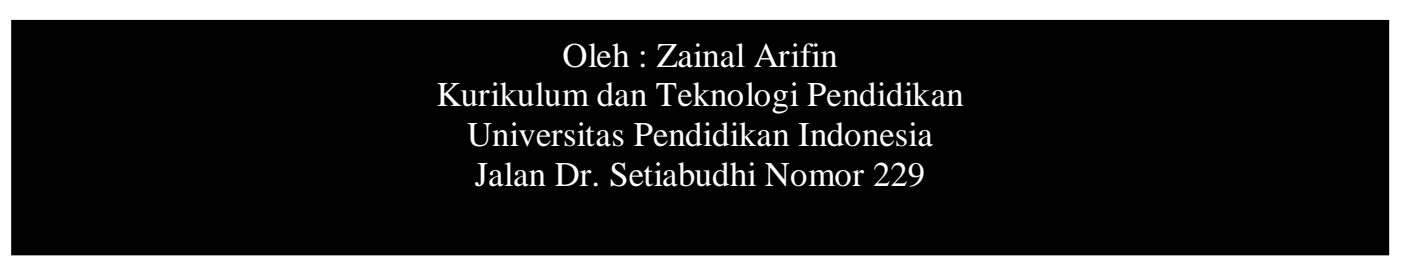

Abstract, Teaching it is an art because every teacher has their own style and characteristics. Therefore, every teacher has different styles and techniques in teaching. So is their performance, models, they ways they deliver the material, the use of methods and media as well as evaluation. In teaching, teachers are expected to not get stuck with the routine of traditional teaching (teacher-centered), which assumes that the learner is an "empty bottle" and must be filled with the knowledge as much as possible. The traditional concept of teaching has long been an issue in education, but in fact until now there are still many teachers who implement such methods at schools. The problem is how to change the paradigm of the teacher to become a professional teacher? How do teachers develop learning system in schools? How do they carry out effective learning? How to prepare teachers for the future? To address these problems, the writer tried to conduct a study of the literature and the results of relevant researches. To change the paradigm of teachers into professional teachers, then there are several requirements that must be met. First, teachers must have a minimum qualification and competence as a teacher candidate. In Indonesia, all teachers (kindergarten, elementary, junior high, high school or equivalent) should have at least relevant diploma (D.IV) or bachelor (S1) degree. Second, they have to understand the developmental level of students. Third, teachers must often be given the opportunity to attend training on the implementation of the curriculum and learning according to each level of education. Fourth, each semester, teachers are required to implement a learning model that can activate learners (student - centered) at school. This means each semester teachers use different learning model which is considered effective and relevant so that within one year there are two models of learning they strongly master in practice. Furthermore, to develop a learning system in schools, there are several things that must be mastered by teachers, among others: the development of strategies that should be considered including the mastery of a foreign language (at least in English), the mastery of pedagogical competence and mastery of ICT (information and communication technology); learning (planning, implementation, and evaluation); organizing the class structure and routines; planning to achieve the objectives, outcomes and standards. To carry out an effective learning, teachers must be able to communicate effectively, use appropriate learning models, conduct classroom management ; use resources creatively, understand individual differences in learning, teach, values and moral education, work effectively with parents, as well as assessing and reporting objectively.

Keywords: professional teacher, teacher-centered, student-centered, effective learning, learning system

Abstrak. Mengajar itu adalah seni, karena setiap guru yang mengajar memiliki gaya dan karakteristik tersendiri. Karena itu, setiap guru mengajar memiliki gaya dan teknik yang berbeda. Begitu juga penampilan, model, cara menyampaikan materi, penggunaan metode dan media maupun evaluasi. Dalam mengajar, diharapkan guru tidak terjebak dengan rutinitas mengajar secara tradisional (teacher-centered), yang menganggap peserta didik itu adalah sebuah "botol kosong" dan harus diisi dengan pengetahuan sebanyakbanyaknya. Konsep mengajar yang tradisional ini sudah lama menjadi isu dalam dunia pendidikan, tetapi faktanya di sekolah, sampai sekarang masih banyak guru yang melaksanakan cara-cara seperti itu. Permasalahannya adalah bagaimana mengubah 
Edutech, Tahun 12, Vol.1, No.3, Oktober 2013

paradigma guru untuk menjadi guru yang profesional ? Bagaimana guru mengembangkan sistem pembelajaran di sekolah ? Bagaimana melaksanakan pembelajaran yang efektif ? Bagaimana mempersiapkan guru untuk masa yang akan datang ? Untuk menjawab permasalahan ini, penulis mencoba melakukan kajian dari berbagai literatur dan hasil penelitian yang relevan.

Untuk mengubah paradigma guru menjadi guru yang profesional, maka ada beberapa syarat yang harus dipenuhi. Pertama, guru harus memiliki kualifikasi dan kompetensi minimal sebagai calon guru. Di Indonesia, semua guru (TK, SD, SMP, SMA dan yang sederajat) minimal harus D.IV atau S.1 (Sarjana) yang relevan. Kedua, memahami tingkat perkembangan siswa. Ketiga, guru harus sering diberi kesempatan untuk mengikuti pelatihan tentang implementasi kurikulum dan pembelajaran sesuai dengan jenjang pendidikannya masing-masing. Keempat, tiap semester, guru diwajibkan untuk menerapkan salah satu model pembelajaran yang dapat mengaktifkan peserta didik (child-centered) di sekolah. Artinya, setiap semester guru harus mengganti model pembelajaran yang dianggap efektif dan relevan, sehingga dalam waktu satu tahun ada dua model pembelajaran yang betul-betul dikuasai guru secara praktis. Selanjutnya, untuk mengembangkan sistem pembelajaran di sekolah, ada beberapa hal yang harus dikuasai guru, antara lain pengembangan strategi yang harus dipertimbangkan, yaitu penguasaan bahasa asing (minimal bahasa Inggris), penguasaan kompetensi pedagogi, dan penguasaan ICT (information and communication technology).pembelajaran (perencanaan, pelaksanaan, dan evaluasi); pengorganisasian struktur kelas dan rutinitas; perencanaan untuk mencapai tujuan, hasil dan standar. Untuk melaksanakan pembelajaran yang efektif, maka guru harus mampu berkomunikasi secara efektif; menggunakan model pembelajaran yang tepat; manajemen kelas; menggunakan sumber daya secara kreatif; memahami perbedaan individu dan belajar; mengajar, nilai, dan pendidikan moral; bekerja secara efektif bersama orang tua; serta melakukan penilaian dan pelaporan secara objektif. Untuk mempersiapkan guru pada masa yang akan datang, ada tiga hal

Kata Kunci : guru profesional, techer-centered, student-centered, pembelajaran yang efektif, sistem pembelajaran

\section{A. PENDAHULUAN}

Belajar menjadi guru adalah sebuah perjalanan yang penting dan menarik karena banyak pengalaman, tantangan dan sukacita yang diperoleh. Tugas dan tanggung jawab guru sangat berat karena bukan hanya tugasnya mentransfer pengetahuan, tetapi lebih dari itu ia harus dapat membentuk pribadi siswa secara utuh. Salah satu tugas guru adalah mengajar, yaitu tugas yang sangat berat dan bermanfaat. Dikatakan berat karena tugas tersebut memiliki tanggung jawab untuk membentuk manusia yang utuh.
Dikatakan mulia karena turut mencerdaskan anak bangsa untuk menjadi orang yang berguna di dunia maupun di akhirat. Di dalam mengajar, guru harus dapat mendorong siswa untuk memperoleh pengalaman dalam mengapresiasi kehangatan, kebersamaan dan kesenangan bagi kedua belah pihak.

Guru memiliki potensi untuk memperkaya kehidupan siswa dalam banyak hal dengan cara mengajar yang terencana, kreatif, interaktif, dan inovatif. Guru juga memiliki potensi untuk 
Edutech, Tahun 12, Vol.1, No.3, Oktober 2013

mengatasi frustasi siswa, membagi waktu dan pengalaman kepada siswa, serta membangun hubungan yang harmonis dengan siswa. Untuk itu, guru harus berkomitmen dan bersedia melakukan pekerjaannya dengan ikhlas dan ekstra sehingga bisa menjadi seorang guru yang profesional. Menjadi seorang guru yang betul-betul "guru" bukanlah suatu pekerjaan yang mudah. Guru itu merupakan suatu profesi yang didalamnya terdapat seperangkat kompetensi yang harus dikuasai guru, baik kompetensi profesional, pedagogik, pribadi maupun kompetensi sosial.

Untuk menjadi seorang guru yang berkemampuan dan kepedulian juga tidaklah gampang. Ia harus menguasai materi pelajaran, membuat perencanaan pembelajaran yang baik, melaksanakan pembelajaran dengan penuh kehangatan, melakukan penilaian dengan cara yang mendidik, dan mendiagonis kesulitan belajar siswa dengan penuh rasa tanggung jawab. Tidak hanya itu, guru juga dituntut untuk mempelajari perkembangan ilmu pengetahuan dan teknologi yang mutahir, sehingga ia tidak ketinggalan zaman. Dalam melaksanakan tugasnya sebagai guru, ia pun harus mematuhi aturan-aturan yang berlaku, termasuk menaati kode etik guru. Ini semua merupakan bahan-bahan kajian yang disajikan dalam buku ini, karena itu pula penulis tertarik untuk mempelajarinya.

\section{B. HASIL DAN PEMBAHASAN \\ 1. Kajian Teori}

\section{a. Guru Profesional}

Guru profesional adalah guru yang memiliki "rasa kemanusiaan dan kehangatan" - untuk mengetahui apa yang dilakukan siswa di kelas setiap saat dan juga untuk peduli tentang apa yang mereka lakukan. Untuk itu, guru harus dibebaskan dari pandanganpandangan negatif tentang guru pada masa lalu, sehingga mereka menjadi "lebih sadar akan apa yang mereka lakukan saat mengajar dan lebih mudah mempertimbangkan praktikpraktik yang belum pernah mereka lakukan". Guru juga harus berani menantang kebiasaan praktik-praktik pembelajaran yang tidak inovatif dan tidak melakukan refleksi. Adapun ciri-ciri pribadi guru yang profesional itu, antara lain : empati dengan siswa, menghormati individu, memiliki pandangan dan sikap positif, memiliki kemampuan melakukan pendekatan, dan rasa humor. Sementara itu, Moyles (1995) mencatat atribut profesional yang diperlukan meliputi : kemampuan organisasi yang baik; hubungan profesional dengan staf, orang tua dan siswa; menghargai keterampilan orang lain. 
Edutech, Tahun 12, Vol.1, No.3, Oktober 2013

Dalam praktik pembelajaran yang profesional adalah guru yang yang tradisional, guru cenderung tidak melakukan refleksi. Padahal refleksi memerlukan refleksi secara kritis atas tindakan yang mereka lakukan dalam itu sangat penting untuk perubahan pembelajaran.

dan perbaikan pembelajaran. Guru

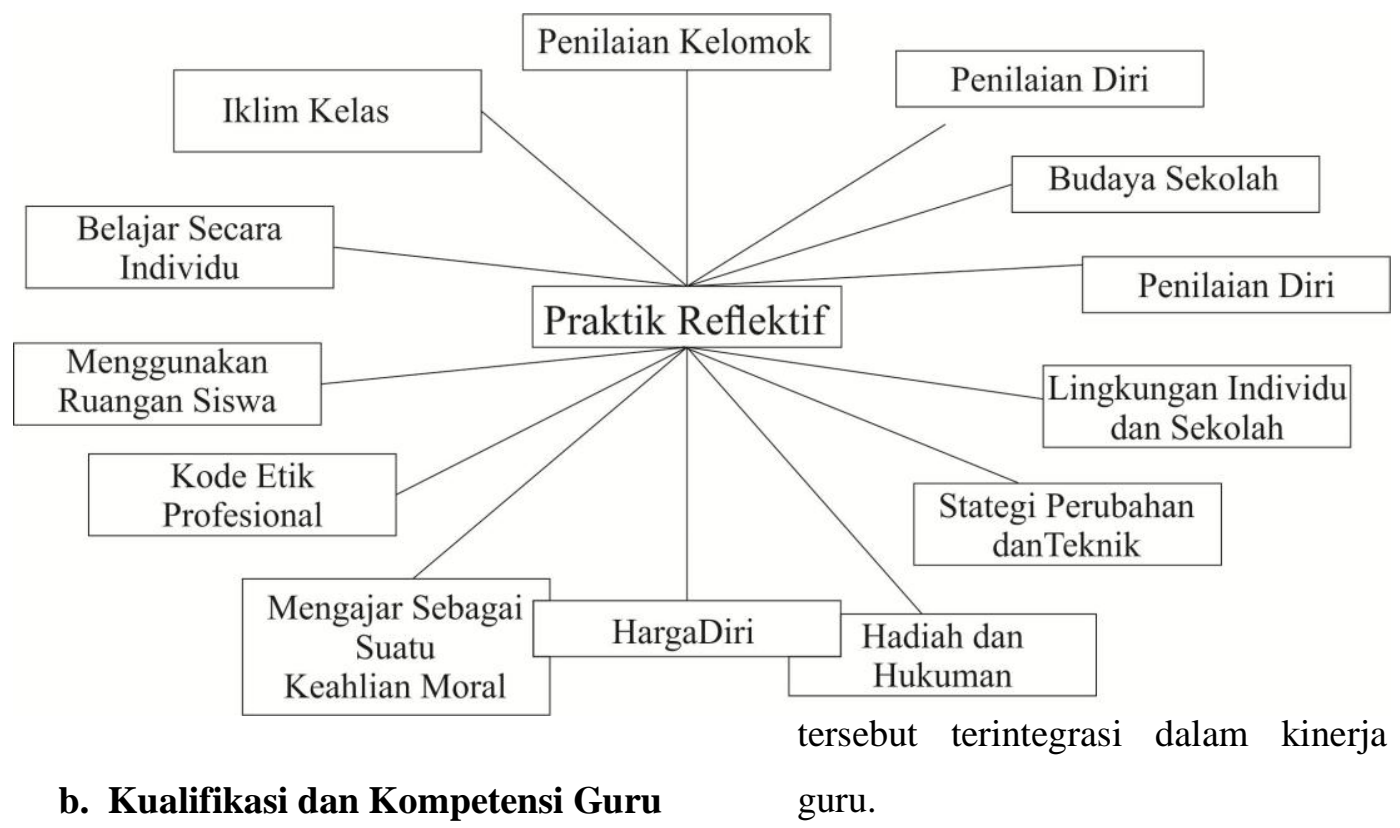

Kajian kompetensi disini mengacu pada Permendiknas No.16 Tahun 2007 tentang Standar Kualifikasi Akademik dan Kompetensi Guru. Dalam peraturan ini dijelaskan bahwa setiap guru wajib memenuhi standar kualifikasi akademik dan kompetensi guru yang berlaku secara nasional, baik melalui jalur pendidikan formal maupun melalui uji kelayakan dan kesetaraan. Sedangkan standar kompetensi guru dikembangkan secara utuh dari empat kompetensi utama, yaitu kompetensi pedagogik, kepribadian, sosial, dan profesional. Keempat kompetensi

\section{c. Tingkat Perkembangan Siswa}

Jean Piaget dan beberapa psikolog lainya, seperti Bruner (1966) and Vygotsky (1978) telah mengembangkan teori-teori kognitif yang menggambarkan bagaimana individu berkembang melalui tahaptahap perkembangan kognitif. Jean Piaget (1896-1980) adalah perintis utama dari teori kognitif. Ia bekerja sebagai seorang psikolog untuk bidang tes, khususnya tes kecerdasan standar anak-anak. Untuk memeriksa jawaban yang 'benar' dan 'salah', anakanak diberikan pertanyaan-pertanyaan spesifik. Mengapa juga anak-anak 
Edutech, Tahun 12, Vol.1, No.3, Oktober 2013

dari usia yang sama dibagikan konsep-konsep yang keliru tetapi serupa. Seharusnya dia mempertimbangkan urutan perkembangan yang bisa menjelaskan pertumbuhan intelektual.

Piaget percaya ada keniscayaan biologis untuk bagaimana anak-anak berkembang. Dia melakukan pengamatan intensif terhadap anakanak secara individual dan melalui metode klinis ini dibentuklah prinsipprinsip teorinya. Piaget berpendapat bahwa ada dua proses yang terlibat bagaimana anak-anak menggunakan dan menyesuaikan skema mereka, yaitu asimilasi dan akomodasi. Asimilasi terjadi ketika seorang anak menggabungkan pengetahuan baru ke dalam pengetahuan yang ada, sedangkan akomodasi terjadi ketika seorang anak menyesuaikan dengan informasi baru. Artinya, asimilasi melibatkan penyesuaian lingkungan ke dalam skema, sedangkan akomodasi menyesuaikan skema untuk lingkungan. Piaget melihat perkembangan kognitif atau intelektual dengan empat tahap, yaitu : (a) sensori-motor (usia $0-2$ tahun), (b) pre-operational (usia $2-7$ tahun), (c) concrete operational (usia 7 - 11 tahun), dan (d) formal operational (usia 11 tahun ke atas).
Jerome Bruner (1966), seorang psikolog kognitif, meneliti pertumbuhan kognitif sebagai hasil dari bekerja dengan anak-anak. Beberapa prinsip yang dipertimbangkannya adalah (a) pertumbuhan intelektual secara langsung berkaitan dengan kemampuan seorang anak untuk menjadi independen dari berbagai tanggapan dan rangsangan, (b) pertumbuhan intelektual seorang anak tergantung pada pengolahan informasi internal dan sistem penyimpanan. Mereka membutuhkan sistem simbol, seperti bahasa, untuk memprediksi, ekstrapolasi dan berpendapat, (c) pengembangan intelektual melibatkan kemampuan anak untuk dapat menggambarkan atau menjelaskan kegiatan masa lalu dan masa yang akan datang, (d) anak-anak membutuhkan interaksi yang sistematis dengan tutor atau orang dewasa lainnya untuk mencapai perkembangan kognitif, (e) anak-anak membutuhkan bahasa untuk berkomunikasi dengan orang lain, bertanya, berhubungan dengan teman baru secara akrab.

Berdasarkan studinya, Bruner mengidentifikasi tiga tahap pertumbuhan, yaitu : 
Edutech, Tahun 12, Vol.1, No.3, Oktober 2013

1) Tahap enactive adalah tahap pertama yang sering dialami oleh anak-anak, terutama ketika belajar sambil berbuat (learning by doing).

2) Tahap iconic yang melibatkan penggunaan citra, bukan bahasa. Anak-anak bertindak berdasarkan kesan-kesan indrawi.

3) Tahap symbolic, yaitu tahap akhir dimana anak-anak memperoleh pemahaman melalui penggunaan sistem simbol.

Vygotsky (1978) terfokus pada dunia sosial anak dan mencatat bahwa budaya seseorang cenderung untuk menentukan rangsangan yang terjadi. Menurutnya, ada empat tahap dalam perkembangan pemikiran : berpikir nonverbal dan berbicara konseptual, (2) mengawali dari penggabungan antara pemikiran dan berbicara, (3) berbicara egosentris (overt), dan (4) berbicara egosentris menjadi tertutup (covert).

\section{d. Kurikulum dan Pembelajaran}

Ketika kita fokus pada kurikulum di sekolah, kita akan menghadapi berbagai interpretasi kurikulum yang berbeda. Bisa jadi kurikulum ditafsirkan sebagai : (a) apa-apa yang diajarkan di sekolah, (b) serangkaian mata pelajaran, (c) isi atau materi, (d) serangkaian bahan- bahan, (e) serangkaian tujuan kinerja untuk belajar siswa di berbagai situs belajar, (f) pengalaman siswa secara individual sebagai hasil dari sekolah, (g) segala sesuatu yang direncanakan oleh personil sekolah, (h) apa yang dikonstruksi siswa melalui bekerja dengan komputer dan berbagai jaringan seperti internet, dan (i) mempertanyakan bidang-bidang otoritas dan mencari pandangan yang lebih kompleks tentang situasi manusia.

Selama periode tertentu, kurikulum selalu mengalami perubahan dan penyempurnaan. Hal ini dimaksudkan agar kurikulum dapat mengikuti perkembangan zaman, termasuk sosial-budaya, dan IPTEK. Seringkali pula, dalam perubahan kurikulum diikuti dengan perubahan strategi pembelajaran. Guru yang profesional tentu harus dapat menguasai setiap perubahan kurikulum, termasuk di dalamnya model pembelajaran sesuai dengan jenjang pendidikan. Disinilah pentingnya guru harus mengikuti pelatihan atau workshop tentang kurikulum dan pembelajaran, terutama menerapkan model pembelajaran tertentu yang relevan. Jika tidak demikian, guru hanya akan mengetahui konsep dan teorinya saja. Inilah yang terjadi selama 
Edutech, Tahun 12, Vol.1, No.3, Oktober 2013

ini di Indonesia. Banyak model pembelajaran yang dikembangkan oleh para ahli, antara lain : model pembelajaran berbasis masalah, model pembelajaran ICARE, model pembelajaran proyek, model pembelajaran kooperatif, model pembelajaran berbasis teknologi informasi, dan lain-lain.

e. Pengembangan

\section{Pembelajaran}

Pengembangan strategi

pembelajaran disini merupakan kegiatan guru dalam perencanaan, pelaksanaan, dan evaluasi pembelajaran. Untuk membuat perencanaan pembelajaran yang efektif, ada beberapa prinsip yang harus diperhatikan guru, yaitu (a) perencanaan secara garis besar merupakan aktivitas mental dan verbal, (b) perencanaan perlu menyatukan perbedaan antara prioritas dan tujuan, (c) perencanaan memerlukan refleksi yang kritis, dan (d) perencanaan perlu mengambil resiko.

Suatu program merupakan representasi/penafsiran kreatif seorang guru dari suatu kurikulum. Hal tersebut harus mengikuti prinsipprinsip pengembangan kurikulum, tetapi penekanan dan kombinasi berbagai kegiatan akan mewakili masing-masing penilaian guru tentang apa yang mereka anggap penting untuk kelas khusus mereka. Unit adalah periode perencanaan yang lebih kecil, biasanya 2 - 6 minggu, serta memiliki fokus dan tema yang ketat daripada suatu program. Rencana Pelaksanaan Pembelajaran (RPP) bahkan lebih bersifat pribadi dimana guru menciptakan kegiatan pembelajaran untuk periode waktu tertentu, sesuai dengan jam pelajaran yang berlaku, yang dapat mengoptimalkan belajar siswa untuk mencapai tujuan tertentu atau memungkinkan siswa untuk menunjukkan hasil-hasil tertentu.

Setelah perencanaan disusun dengan baik, maka tugas guru selanjutnya adalah melaksanakan kegiatan pembelajaran. Disini, guru harus menguasai materi, metode, media, sumber belajar, lingkungan, dan tingkat perkembangan siswa. Guru juga harus mampu berkomunikasi dengan efektif, menciptakan suasana pembelajaran yang kondusif dan menarik, sehingga dapat menumbuhkan motivasi belajar siswa. Motivasi terdiri atas dua jenis, yaitu motivasi internal dan motivasi eksternal. Motivasi intrinsik mengacu pada motivasi tanpa imbalan eksternal yang jelas, misalnya motivasi untuk 
Edutech, Tahun 12, Vol.1, No.3, Oktober 2013

belajar yang berasal sepenuhnya dari melakukan tugas tertentu. Motivasi ekstrinsik dialami oleh siswa ketika mereka menerima hadiah atau menghindari hukuman, atau dengan cara-cara lain yang tidak terkait dengan tugasnya atau tidak mendapatkan persetujuan untuk perilaku tertentu. Dalam istilah teknis kita bisa merujuk pada penguatan (reinforcement), yang merupakan stimulus eksternal sebagai hasil dari respon tertentu.

Sejumlah pendidik menyatakan bahwa harga diri adalah salah satu kebutuhan manusia yang paling mendasar dan itu merupakan faktor yang penting dalam perilaku kelas. Maslow (1954) berpendapat bahwa motivasi dapat dikelompokkan ke dalam hirarki kebutuhan, dan harga diri termasuk dalam hirarki ini. Maslow juga berpendapat bahwa ada empat kebutuhan pada tingkat yang lebih rendah, yaitu bertahan hidup (survival), keamanan (safety), memiliki (belonging), dan harga diri (self-esteem), dimana setiap individu akan berusaha untuk memilikinya.

Pada akhirnya, guru juga harus menguasai pengembangan sistem evaluasi pembelajaran sesuai dengan tuntutan kurikulum yang berlaku, baik itu konsep, prinsip, teknik, prosedur maupun model-model evaluasi yang digunakan. Penguasaan evaluasi sebagai bagian integral dari kurikulum dan pembelajaran sudah menjadi tuntutan dan keharusan bagi guru profesional untuk menguasainya.

\section{f. Lingkungan Belajar}

Guru dan siswa memiliki kesempatan untuk mengekspresikan "kepribadiannya" melalui penataan dan dekorasi lingkungan serta penataan ruang. Namun, pengaturan kreatif memerlukan pengetahuan karena kondisi fisik tertentu dan alokasi ruang memiliki konsekuensi penting terhadap sikap, perilaku bahkan prestasi siswa. Untuk itu, guru harus memahami prinsip-prinsip pengaturan ruangan, yaitu : (a) gunakan pengaturan ruang yang mempermudah aktifitas mengajar dan gaya belajar siswa serta tidak menghambat, (b) bagi sekolah yang berada di daerah lalu lintas ramai, ruangannya harus terbuka dan tidak padat, (c) harus ada garis yang jelas dan terlihat antara tempat duduk siswa dengan guru, dan (d) bahan-bahan pembelajaran yang sering digunakan harus tersedia dan mudah diakses. Di samping itu, guru perlu memperhatikan teknik pengaturan ruangan, seperti : luas lantai setiap ruangan, lokasi tempat duduk guru, 
Edutech, Tahun 12, Vol.1, No.3, Oktober 2013

tempat duduk siswa, perabot dan peralatan, ruangan belajar dan tempat bekerja khusus, pin-up boards dan bulletin boards, whiteboards interaktif, dan tempat-tempat khusus lainnya. Di samping itu, guru perlu memperhatikan faktor-faktor fisik dan psikologis ruangan kelas, seperti : warna, suara bising, temperatur udara, tempat duduk, ukuran kelas, dan lingkungan psikologis.

\section{g. Pentingnya Tujuan, Hasil dan \\ Standar}

Tujuan sangat membantu guru dalam perencanaan, terutama yang berhubungan dengan pengembangan program dan rencana pelajaran. Bagi seorang perencana (guru) landasannya adalah tujuan yang dinyatakan secara jelas dan tidak diragukan lagi. Beberapa guru menolak menggunakan tujuan karena mereka menganggap terlalu membatasi atau tidak sesuai untuk konten tertentu yang tidak dapat didefinisikan secara spesifik atau dievaluasi. Namun seorang ahli pengukuran, seperti Mager (1984) menjelaskan "jika Anda mengajar halhal yang tidak dapat dievaluasi, Anda berada dalam posisi yang canggung karena tidak dapat menunjukkan bahwa Anda sedang mengajar sesuatu untuk semua. Berwujud tapi sering tidak berwujud karena kita terlalu malas untuk berpikir tentang apa yang kita inginkan, siswa dapat melakukannya". Selanjutnya, Willis dan Kissane (1997) mendefinisikan hasil sebagai "deskripsi yang luas tentang kompetensi siswa, yang merupakan refleksi dari pembelajaran di sekolah maupun di luar sekolah dengan waktu yang cukup lama, dari kompetensi yang sangat luas menjadi lebih terperinci, dari berbagai isi kurikulum, urutan atau pedagogi". Hasil lebih berkonsentrasi pada output daripada input pengajaran, sedangkan tujuan hanya berkonsentrasi pada input pengajaran.

Tabel 1 :Langkah-langkah Perencanaan Pembelajaran Berorientasi Pada Hasil

\begin{tabular}{|c|l|l|}
\hline No & \multicolumn{1}{|c|}{ Langkah-langkah } & \multicolumn{1}{c|}{ Pertanyaan Kunci } \\
\hline 1 & Memahami hasil & Memperjelas apa hasilnya bagi Anda ? \\
\hline 2 & $\begin{array}{l}\text { Mempertimbangkan bagaimana } \\
\text { hasil ini terkait dengan hasil-hasil } \\
\text { lain atau bidang studi pokok }(k e y \\
\text { learning areas/KLAs) }\end{array}$ & $\begin{array}{l}\text { Apakah ada hasil yang lain atau KLAs } \\
\text { yang terkait dengan hasil ini? dalam hal } \\
\text { apa? apah ada kesempatan untuk } \\
\text { pembelajaran terpadu? }\end{array}$ \\
\hline 3 & Menguraikan hasil & $\begin{array}{l}\text { Pertimbangkan beberapa konsep utama, } \\
\text { keterampilan atau nilai-nilai, apakah ide- } \\
\text { ide besar mendukung itu? }\end{array}$ \\
\hline
\end{tabular}


Edutech, Tahun 12, Vol.1, No.3, Oktober 2013

\begin{tabular}{|c|l|l|}
\hline 4 & $\begin{array}{l}\text { Apakah ide-ide tentang hasilnya } \\
\text { merupakan hal yang baru bagi } \\
\text { siswa? }\end{array}$ & $\begin{array}{l}\text { Apakah mencakup siswa pada masa lalu, } \\
\text { semester lalu? }\end{array}$ \\
\hline 5 & $\begin{array}{l}\text { Pertimbangkan sejauh mana siswa } \\
\text { dapat mencapai hasil ini }\end{array}$ & $\begin{array}{l}\text { Periksa pada pemahaman siswa saat ini, } \\
\text { termasuk keterampilannya. }\end{array}$ \\
\hline 6 & $\begin{array}{l}\text { Selidiki mengapa siswa tidak } \\
\text { mencapai hasil pada aspek-aspek } \\
\text { tertentu? }\end{array}$ & $\begin{array}{l}\text { Apakah informasi diagnostik pada siswa } \\
\text { tersedia? }\end{array}$ \\
\hline 7 & $\begin{array}{l}\text { Pertimbangkan apakah urutan } \\
\text { belajar yang berbeda diperlukan } \\
\text { untuk hasil ini ? perubahan yang }\end{array}$ & $\begin{array}{l}\text { Apakah kegiatan siswa yang berbeda } \\
\text { diperlukan? mengapa? }\end{array}$ \\
\hline 8 & $\begin{array}{l}\text { Menyelidiki pagaimana kegiatan siswa baru yang } \\
\text { dibutuhkan untuk strategi penilaian } \\
\text { memerlukan perubahan bentuk dan/atau } \\
\text { frekuensi penilaian? }\end{array}$ \\
\hline 9 & $\begin{array}{l}\text { Memodifikasi atau mengubah } \\
\text { pengalaman belajar yang } \\
\text { direncanakan }\end{array}$ & $\begin{array}{l}\text { Apakah ada perubahan lain yang } \\
\text { dibutuhkan? mengapa? }\end{array}$ \\
\hline 10 & $\begin{array}{l}\text { Menilai prestasi siswa dengan } \\
\text { menggunakan hasilnya }\end{array}$ & $\begin{array}{l}\text { Bagaimana kesuksesan siswa dalam } \\
\text { menghadapi hasil yang ada? Bukti apa } \\
\text { yang Anda kumpulkan tentang kegiatan } \\
\text { siswa? }\end{array}$ \\
\hline 11 & $\begin{array}{l}\text { Apakah berhasil dan tidak berhasilnya } \\
\text { siswa merupakan fitur pembelajaran yang } \\
\text { berorientasi pada hasil? perubahan apa } \\
\text { yang akan Anda lakukan pada masa yang } \\
\text { akan datang? }\end{array}$ \\
\hline
\end{tabular}

Suatu pembedaan harus dibuat antara isi dan standar kinerja. Standar isi menjelaskan pengetahuan yang akan diperoleh, apakah itu proses atau konten. Standar kinerja merupakan tugas yang harus diselesaikan oleh

$\begin{array}{lrr}\text { siswa, sementara } & \text { pengetahuan } \\ \text { termasuk dalam tugas } & \text { tersebut dan } \\ \text { siswa harus } & \text { menggunakan } \\ \text { pengetahuan } \quad \text { serta } & \text { keterampilan } \\ \text { dengan } & \text { cara } & \text { tertentu }\end{array}$

Tabel 2 : Perbedaan Antara Silabus, Hasil, dan Standar

\begin{tabular}{|l|l|lr|}
\hline \multicolumn{1}{|c|}{ Silabus } & \multicolumn{2}{|c|}{ Hasil } & \multicolumn{2}{|c|}{ Standar } \\
\hline $\begin{array}{l}\text { Fokus pada apa yang harus } \\
\text { dipikirkan atau diharapkan } \\
\text { siswa untuk belajar }\end{array}$ & $\begin{array}{l}\text { Fokus pada apa yang harus } \\
\text { dicapai atau dilakukan } \\
\text { siswa }\end{array}$ & $\begin{array}{l}\text { Menemukan apa yang } \\
\text { harus diketahi dan } \\
\text { dilakukan siswa }\end{array}$ \\
\hline $\begin{array}{l}\text { Berdasarkan pada mata } \\
\text { pelajaran/kategori } \\
\text { pengetahuan yang telah } \\
\text { ditetapkan mata }\end{array}$ & $\begin{array}{l}\text { Campuran dari dengan } \\
\text { pelajaran } \\
\text { pendekatan berbagai mata } \\
\text { pelajaran yang ditetapkan } \\
\text { pelajaran/kategori } \\
\text { pengetahuan yang telah } \\
\text { ditetapkan }\end{array}$ \\
\hline
\end{tabular}


Edutech, Tahun 12, Vol.1, No.3, Oktober 2013

\begin{tabular}{|c|c|c|}
\hline $\begin{array}{l}\text { Berhubungan dengan } \\
\text { tingkatan kelas/tahun yang } \\
\text { spesifik }\end{array}$ & $\begin{array}{l}\text { Ditujukan untuk berbagai } \\
\text { tingkat } \\
\text { menggabungkan sejumlah } \\
\text { tingkatan kelas / tahun }\end{array}$ & $\begin{array}{l}\text { Secara umum fokus pada } \\
\text { tingkatan kelas/tahun }\end{array}$ \\
\hline $\begin{array}{l}\text { Fokus pada pengetahuan, } \\
\text { pemahaman dan } \\
\text { keterampilan yang penting } \\
\text { yang dapat dikuasai pada } \\
\text { tahap-tahap utama } \\
\text { (cakupan tes dan } \\
\text { streaming yang tinggi) }\end{array}$ & $\begin{array}{l}\text { Pengembangan, pendekatan } \\
\text { konstruktivis } \\
\text { pembelajaran }\end{array}$ & $\begin{array}{l}\text { Fokus pada pengetahuan, } \\
\text { pemahaman dan } \\
\text { keterampilan yang penting } \\
\text { yang dapat dikuasai pada } \\
\text { tahap-tahap utama } \\
\text { (beberapa negara } \\
\text { mengharapkan siswa untuk } \\
\text { mengulang kelas jika } \\
\text { standar tidak terpenuhi) }\end{array}$ \\
\hline $\begin{array}{l}\text { Lebih besar penekanannya } \\
\text { pada apa yang diarahkan } \\
\text { guru, mengajar seluruh } \\
\text { kelas }\end{array}$ & $\begin{array}{l}\text { Individualistik, pendekatan } \\
\text { pembelajaran berpusat pada } \\
\text { anak (siswa) }\end{array}$ & $\begin{array}{l}\text { Lebih besar penekanannya } \\
\text { pada apa yang diarahkan } \\
\text { guru, mengajar seluruh } \\
\text { kelas }\end{array}$ \\
\hline $\begin{array}{l}\text { Kurikulum umum, atau } \\
\text { dalam jalur kurikuler yang } \\
\text { berbeda dan terpisah, } \\
\text { berdasarkan kurikulum inti } \\
\text { ditambah materi pilihan } \\
\text { dimana pendekatan jalur } \\
\text { digunakan }\end{array}$ & Kurikulum umum & Kurikulum inti/pilihan \\
\hline $\begin{array}{llll}\text { Bidang } & \text { studi dan topik } \\
\text { terpisah } & & & \\
\end{array}$ & $\begin{array}{l}\text { Topik-topik } \quad r \text { tertentu } \\
\text { (seperti sastra atau } \\
\text { geometri) yang sering } \\
\text { tersebar di seluruh alur }\end{array}$ & Topik-topik terpisah \\
\hline Jumlah jam ditetapkan & Jumlah jam tidak ditetapkan & $\begin{array}{ll}\text { Jumlah } & \text { jam } \\
\text { ditetapkan } & \\
\end{array}$ \\
\hline
\end{tabular}

h. Pembelajaran Efektif

\section{1) Berkomunikasi Secara Efektif}

Salah satu cara untuk mencoba menganalisis komunikasi adalah mengelompokkannya dalam tiga set keterampilan, yaitu keterampilan bahasa, keterampilan sosial, dan keterampilan kognitif. Guru juga perlu membedakan antara jenis bahasa yang digunakan, karena mungkin verbal dan/atau non-verbal. Komunikasi verbal adalah apa yang dilakukan guru-guru dalam memanfaatkan sebagian besar waktunya, seperti guru sering berbicara di dalam kelas. Sedangkan komunikasi non-verbal digunakan guru-guru untuk mendukung komunikasi verbalnya.

2) Model Pembelajaran.

Guru sering didesak untuk menggunakan berbagai model pembelajaran sehingga minat dan kemampuan siswa yang beragam dapat ditampung. Namun, guru terbatas dalam menggunakan model 
Edutech, Tahun 12, Vol.1, No.3, Oktober 2013

pembelajaran, padahal mereka dapat menggunakannya, karena : pembatasan kemampuan dan minat siswa, tingginya jumlah siswa dalam satu kelas, keterbatasan ruang mengajar, latar belakang atau pengetahuan tentang model pembelajaran khusus tidak cukup, dan jenis teknologi yang tersedia kurang mendukung. Beberapa model pembelajaran yang dapat digunakan guru, antara lain : pemecahan masalah/inkuiri, bermain peran, simulasi, kegiatan kelompok kecil, pembelajaran online, pembelajaran kooperatif, pembelajaran berbasis proyek, dll.

\section{3) Manajemen Kelas}

Beberapa program yang telah digunakan dalam manajemen kelas, antara lain : program tradisional berdasarkan teori penguatan; program ditujukan ke arah pengelolaan diri (self-management) dan masyarakat; program yang mempedulikan kelas berdasarkan konstruktivis, prinsipprinsip yang berpusat pada siswa; program yang menekankan pada kegiatan berbasis penyelidikan (inquiry-based activities), tanggung jawab siswa, dan tanggung jawab organisasi diri; program yang menekankan kepemimpinan guru yang tegas.

\section{4) Menggunakan Sumber Daya Secara Kreatif}

Seperti dicatat oleh Davis dan Krajcik (2005), sumber daya sangat berharga bagi guru untuk digunakan dengan siswa, tetapi juga edukasi bagi guru dalam hal membantu mereka belajar bagaimana mengantisipasi dan menafsirkan apakah siswa dapat berpikir dalam menanggapi kegiatan pembelajaran, membantu mereka mempelajari materi pelajaran, dan membantu mereka untuk mempertimbangkan bagaimana sumber daya dapat digunakan dengan unit lain selama setahun.

Berbagai jenis sumber daya yang dapat digunakan di dalam kelas : (a) bahan-bahan cetak, seperti buku teks, buku referensi, project kits, pamplet dan bahan-bahan yang tidak mahal, poster, permainan simulasi, peta, globe, model, dll (b) multi media, seperti : personal computers, tablet $P C s, P D A s$, internet dan WWW, CDROM, DVD, blogs, televisi dan videotapes, film, radio, slidetapes and filmstrips, overhead projectors, powerpoint projectors, interactive whiteboards, dll (c) sumber-sumber budaya, meliputi : museum, galeri seni, perpustakaan, arsip, dll (d) manusia sumber, mencakup : orang dalam pekerjaan khusus, orang 
Edutech, Tahun 12, Vol.1, No.3, Oktober 2013

pensiunan, kelompok, asosiasi, dan organisasi, dan (e) bahan dan artefak, seperti : koran, dokumen dan laporan, potografi, rekaman, dan aneka barang pribadi.

\section{5) Perbedaan Individu dan Belajar}

Pada umumnya, model pembelajaran yang terjadi di kelas melibatkan kelas secara keseluruhan atau kelompok kecil. Siswa hanya diberi kesempatan untuk melakukan belajar mandiri dan dapat bekerja sendiri. Alasannya antara lain guru akan kesulitan waktu untuk mempersiapkan kegiatan terpisah bagi 30 orang siswa atau lebih; akan ada masalah dalam menemukan sumber daya yang cukup dan ruang untuk menampung semua kegiatan individu; akan ada masalah pengawasan utama yang akan menyebabkan kenakalan dan masalah disiplin. Tentu saja ada beberapa pendekatan spesifik yang dapat digunakan termasuk : kontrak, pusat pembelajaran, pembelajaran berbasis komputer, lesson study, penguasaan belajar, kecerdasan ganda, pendidikan berbasis hasil, dan pendidikan berbasis standar.

6) Pengajaran, Nilai dan Pendidikan Moral

Nilai dan sikap berkaitan dengan komponen perasaan dari perilaku manusia. Nilai cenderung relatif stabil seperti kecenderungan kita untuk berperilaku dengan cara-cara tertentu. Berbagai faktor mempengaruhi perkembangan nilai termasuk orang tua, teman sebaya, media dan lainlain. Guru diharapkan dapat menggunakan "kekuasaan" mereka di kelas dengan memuji dan bertindak atas nilai-nilai seperti : (a) membangun hubungan baik dan mengembangkan hubungan khusus dengan siswa, (b) mengekspresikan empati bagi siswa dan masalahmasalahnya, (c) melindungi hak-hak semua pihak ketika muncul dilema moral di dalam kelas, (d) menghadapi masalah etika dengan keberanian dan keyakinan, dan (e) mengandalkan pada keterampilan komunikasi yang efektif untuk menyelesaikan masalah.

7) Bekerja Secara Efektif dengan

\section{Orang Tua}

Sebenarnya, banyak cara agar orang tua dapat bekerjasama dengan pihak sekolah yang dilakukan secara bervariasi. Keterlibatan orang tua kebanyakan hanya terbatas untuk menghadiri suatu pertemuan, seperti: malam orangtua-guru (parent-teacher nights), hari olahraga sekolah (school sports days), fetes, tuck shops, working bees, pertemuan orang tua dan warga atau orang tua dan temanteman, pertemuan dewan sekolah, dll. 
Edutech, Tahun 12, Vol.1, No.3, Oktober 2013

McGilp dan Michael (1994) menyarankan orang tua dapat terlibat sebagai audience, spektator, pengumpul dana, pembantu penyelenggara kegiatan, instruktur, pembuat kebijakan, pengambil keputusan dan pendukung kegiatan di sekolah.

\section{8) Penilaian dan Pelaporan}

Penilaian adalah istilah yang biasanya digunakan untuk menggambarkan kegiatan yang dilakukan oleh guru untuk memperoleh informasi tentang pengetahuan, keterampilan, dan sikap siswa. Beberapa prinsip dasar penilaian, antara lain: (a) penilaian hanya dapat dilakukan berdasarkan pada sampel perilaku dan karena itu sering terjadi ketidakakuratan; (b) penilaian harus dikomunikasikan dengan guru bagaimana membuat pembelajaran lebih efektif; (c) penilaian tidak dilakukan terutama untuk mempromosikan pembelajaran; (d) penilaian harus adil untuk semua individu dan kelompok; (e) penilaian harus mengukur berbagai kemampuan; dan (f) hasil penilaian harus bermakna untuk semua pihak yang berpartisipasi, siswa, guru dan orang tua. Penilaian perlu dilakukan dengan alasan : diagnosis dan pemantauan kemajuan belajar, peringkat siswa; memprediksi prestasi masa depan; memotivasi siswa, dan diagnosis pembelajaran.

\section{Pembahasan}

Untuk menjadi seorang guru yang profesional tentu tidaklah mudah, banyak kompetensi yang harus dipahami dan dikuasai oleh calon guru, baik yang berkenaan dengan pengetahuan keguruan itu sendiri, keterampilan mengajar dan membimbing, dan mengembangkan sikap dan kepribadian guru.

Apa yang dikemukakan Hughes (2004) bahwa seorang guru harus memiliki "rasa kemanusiaan dan kehangatan" untuk mengetahui apa yang dilakukan siswa di kelas setiap saat dan juga untuk peduli tentang apa yang mereka lakukan merupakan suatu pemikiran yang cerdas. Menurut penulis, paling tidak ada dua hal yang melatarbelakangi pemikiran tersebut. Pertama, tugas guru tidak semata-mata mengajar tetapi juga mendidik. Banyak orang yang bisa mengajar tetapi belum tentu bisa mendidik, karena mendidik lebih banyak berkaitan dengan aspek afeksi dan nilai. Kedua, siswa adalah manusia yang mempunyai perasaan dan harga diri. Siswa bukanlah "botol kosong" yang bisa diisi oleh apa saja tanpa adanya reaksi. Oleh karena itu, dalam mengajar guru harus melakukannya dengan penuh rasa kemanusiaan dan kehangatan. Untuk 
Edutech, Tahun 12, Vol.1, No.3, Oktober 2013

memahami konsep mengajar ini, mari kita lihat beberapa pendapat berikut ini.

$$
\text { Burton dalam Usman (1994) }
$$
menegaskan "teaching is the guidance of learning activities". Lebih jauh lagi, Oemar Hamalik (2001) mengemukakan, mengajar dapat diartikan sebagai (1) menyampaikan pengetahuan kepada siswa, (2) mewariskan kebudayaan kepada generasi muda, (3) usaha mengorganisasi lingkungan sehingga menciptakan kondisi belajar bagi siswa, (4) memberikan bimbingan belajar kepada murid, (5) kegiatan mempersiapkan siswa untuk menjadi warga negara yang baik, (6) suatu proses membantu siswa menghadapi kehidupan masyarakat sehari-hari. Selanjutnya, Tardif dalam Adrian (2004) mendefinisikan mengajar sebagai "any action performed by an individual (the teacher) with the intention of facilitating learning in another individual (the learner)". Mengajar adalah perbuatan yang dilakukan seseorang (guru) dengan tujuan membantu atau memudahkan orang lain (peserta didik) melakukan kegiatan belajar.

Biggs dalam Adrian (2004) seorang pakar psikologi membagi konsep mengajar menjadi tiga macam pengertian, yaitu "pengertian kuantitatif, pengertian institusional, dan pengertian kualitatif". Dalam pengertian kuantitatif, mengajar diartikan sebagai the transmission of knowledge, yakni penyampaian pengetahuan. Guru hanya perlu menguasai pengetahuan bidang studinya dan menyampaikan kepada siswa dengan sebaik-baiknya. Masalah berhasil atau tidaknya siswa bukan tanggung jawab guru. Dalam pengertian institusional, mengajar berarti the efficient orchestration of teaching skills, yakni penataan keterampilan mengajar secara efisien. Guru harus selalu siap mengadaptasikan berbagai teknik mengajar terhadap siswa yang memiliki berbagai macam tipe belajar serta berbeda bakat, kemampuan dan kebutuhannya. Dalam pengertian kualitatif, mengajar diartikan sebagai the facilitation of learning, yaitu upaya membantu memudahkan kegiatan belajar siswa mencari makna dan pemahamannya sendiri.

Dalam pembelajaran, guru mempunyai tugas pokok sebagai pembuat keputusan yang berhubungan dengan perencanaan, implementasi, dan evaluasi.

\section{Membuat}

Perencanaan

\section{Pembelajaran}

Dalam mengembangkan perencanaan pembelajaran, guru harus mengetahui unsur-unsur perencanaan pembelajaran yang baik. Menurut Hunt (1999), unsur-unsur perencanaan pembelajaran tersebut adalah mengidentifikasi kebutuhan siswa, tujuan yang hendak dicapai, berbagai 
Edutech, Tahun 12, Vol.1, No.3, Oktober 2013

strategi dan skenario yang relevan untuk mencapai tujuan, dan kriteria evaluasi. Peran guru bukan hanya sebagai transformator, tetapi harus berperan sebagai motivator yang dapat membangkitkan gairah belajar, serta mendorong siswa untuk belajar dengan menggunakan berbagai variasi media, dan sumber belajar yang sesuai serta menunjang penguasaan kompetensi.

Rencana pembelajaran yang baik menurut Gagne dan Briggs (1974) hendaknya mengandung tiga komponen yang disebut anchor point, yaitu: (1) tujuan pembelajaran; (2) materi pembelajaran, bahan ajar, pendekatan dan metode mengajar, media pengajaran dan pengalaman belajar; dan (3) evaluasi keberhasilan.

Hal ini sesuai dengan pendapat Moore (2001) bahwa komposisi format rencana pembelajaran meliputi komponen topik bahasan, tujuan pembelajaran (kompetensi dasar dan indikator), materi pelajaran, kegiatan pembelajaran, alat/media yang dibutuhkan, dan penilaian hasil belajar. Artinya, suatu program pembelajaran harus mendekripsikan proyeksi guru mengenai kegiatan yang akan dilakukan siswa selama pembelajaran berlangsung. Dalam kegiatan tersebut secara terperinci dijelaskan ke mana siswa itu akan dibawa (tujuan), apa yang harus dipelajari (isi bahan pelajaran), bagaimana siswa mempelajarinya (metode dan teknik), dan bagaimana kita mengetahui bahwa siswa telah mencapainya (penilaian).

\section{Melaksanakan Pembelajaran}

Pelaksanaan pembelajaran tentunya harus sesuai tahapan-tahapan tertentu, meliputi tahap orientasi, tahap inti, dan tahap kulminasi. Secara teknis, pelaksanaan pembelajaran itu dimulai dari membuka pelajaran; menyampaikan isi/materi; mengelola kegiatan pembelajaran; mengorganisasikan waktu, siswa, sarana dan prasarana pembelajaran; menilai proses dan hasil belajar; dan menutup pelajaran.

\section{Mengevaluasi Pembelajaran}

Hasil evaluasi sangat penting bagi guru karena dapat digunakan sebagai balikan maupun keputusan yang sangat diperlukan dalam menentukan strategi pembelajaran yang tepat maupun dalam memperbaiki proses pembelajaran. Untuk itu, guru harus melakukan evaluasi, baik terhadap proses maupun terhadap hasil belajar. Tugas guru antara lain membuat perencanaan evaluasi, mengumpulkan data, mengolah dan menafsirkan data, 
Edutech, Tahun 12, Vol.1, No.3, Oktober 2013

membuat keputusan, dan memberikan laporan kepada berbagai pihak yang berkepentingan. Hasil evaluasi yang dilakukan guru perlu ditindaklanjuti. Artinya, setelah kegiatan pembelajaran berakhir, tentu ada siswa yang dapat menguasai materi pelajaran, dan ada juga siswa yang tidak menguasai materi pelajaran dengan baik, sebagaimana tercermin dalam buku raport. Berkaitan dengan hal ini, guru perlu melakukan upaya perbaikan, pembelajaran remedial, program akselerasi, pembinaan sikap dan kebiasaan belajar yang baik, dan peningkatan motivasi belajar.

Dalam menjalankan tugas mengajar, guru harus memahami terlebih dahulu teori perkembangan kognitif sebagaimana telah dikemukakan kajian teoritik. Teori ini membahas munculnya dan diperolehnya schemata-skema tentang bagaimana seseorang mempersepsi lingkungannya. Dalam tahapan-tahapan perkembangannya, seseorang memperoleh cara baru dalam merepresentasikan informasi secara mental. Teori ini digolongkan ke dalam konstruktivisme, yang berarti, tidak seperti teori nativisme (yang menggambarkan perkembangan kognitif sebagai pemunculan pengetahuan dan kemampuan bawaan). Teori ini berpendapat bahwa kita membangun kemampuan kognitif melalui tindakan yang termotivasi dengan sendirinya terhadap lingkungan. Untuk pengembangan teori ini, Piaget memperoleh Erasmus Prize.

\section{Peran Guru Sebagai Motivator :}

Secara etimologis, Winardi (2002) menjelaskan istilah motivasi (motivation) berasal dari perkataan bahasa Latin, yakni movere yang berarti menggerakkan (to move). Diserap dalam bahasa Inggris menjadi motivation berarti pemberian motif, penimbulan motif atau hal yang menimbulkan dorongan atau keadaan yang menimbulkan dorongan. Ditegaskan Winardi, bahwa motivasi seseorang tergantung kepada kekuatan motifnya. Berdasarkan hal tersebut diskusi mengenai motivasi tidak bisa lepas dari konsep motif. Pada intinya dapat dikatakan bahwa motif merupakan penyebab terjadinya tindakan. Steiner dalam Hasibuan (2003) mengemukakan motif adalah "suatu pendorong dari dalam untuk beraktivitas atau bergerak dan secara langsung atau mengarah kepada sasaran akhir”. Dengan kata lain, motif merupakan sebab-sebab yang menjadi dorongan tindakan seseorang. Hubungan antara motif, tujuan, dan 
aktivitas dapat ditunjukan pada gambar berikut ini.

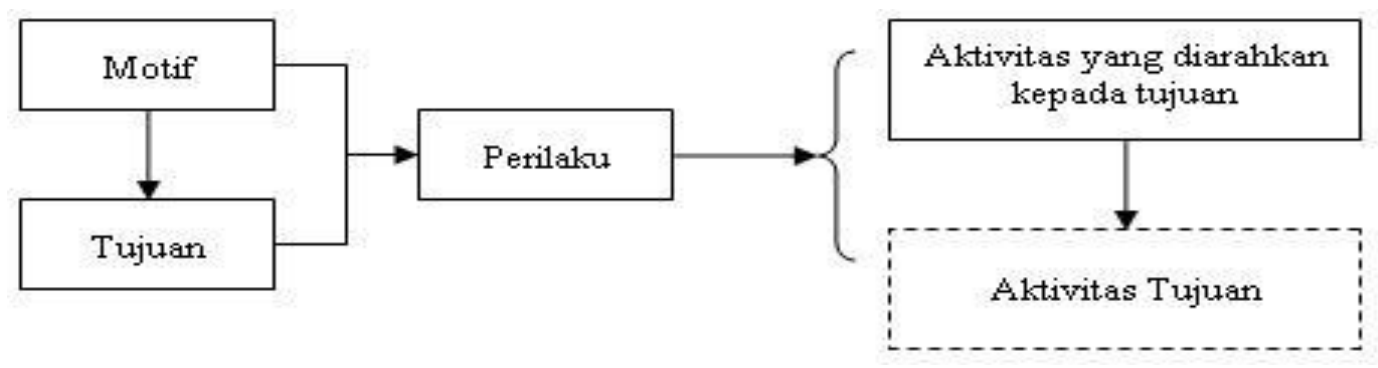

Gambar 1 : Sebuah Situasi yang Memotivasi (Winardi, 2002)

Gambar 1 menunjukkan sebuah situasi yang memotivasi, di mana motif-motif seorang individu, diarahkan kepada pencapaian tujuan. Motif terkuat, menimbulkan perilaku, yang bersifat diarahkan kepada tujuan atau aktivitas tujuan. Mengingat bahwa tidak semua tujuan dapat dicapai, maka para individu tidak selalu mencapai aktivitas tujuan, terlepas dari kekuatan motif yang ada. Dengan demikian, aktivitas tujuan dinyatakan dalam gambar berupa garis putus-putus. Dalam konsep motif terkandung makna (1) motif merupakan daya pendorong dari dalam diri individu, (2) motif merupakan penyebab terjadinya aktivitas, dan (3) motif diarahkan untuk mencapai tujuan tertentu. Dengan demikian motif dapat didefinisikan sebagai daya pendorong dari dalam diri individu sebagai penyebab terjadinya aktivitas, yang diarahkan untuk mencapai tujuan tertentu.
Mathis and Jackson (2000) mengemukakan motivasi merupakan hasrat di dalam seseorang yang menyebabkan orang tersebut melakukan tindakan. Chung \& Megginson dalam Gomes (2001) menjelaskan motivation is defined as goal-directed behavior. It concerns the level of effort one exerts in pursuing a goal... it is closely related to employee satisfaction and job performance (motivasi dirumuskan sebagai perilaku yang ditujukan pada sasaran motivasi berkaitan dengan tingkat usaha yang dilakukan oleh seseorang dalam mengejar suatu tujuan... motivasi berkaitan erat dengan kepuasan pekerjaan dan performansi pekerjaan). Jones dalam Indrawijaya (1989) merumuskan motivation is concerned with how behavior is activated, maintained, directed, and stopped. Duncan dalam Indrawijaya, (1989) mengatakan from a managerial perspektif, motivation refers to any 
Edutech, Tahun 12, Vol.1, No.3, Oktober 2013

conscious attempt to influence behavior toward the accomplishment of organization goals.

Motivasi adalah suatu proses psikologi yang mencerminkan interaksi antara sikap, kebutuhan, persepsi, dan keputusan yang terjadi pada diri seseorang. Proses psikologi timbul diakibatkan oleh faktor di dalam diri seseorang itu sendiri yang disebut intrinsic dan extrinsic. Faktor di dalam diri seseorang bisa berupa kepribadian, sikap, pengalaman dan pendidikan, atau berbagai harapan, cita-cita yang menjangkau ke masa depan, sedang faktor dari luar diri dapat ditimbulkan oleh berbagi faktor-faktor lain yang sangat kompleks. Baik faktor ekstrinsik maupun faktor intrinsik motivasi timbul karena adanya rangsangan. Motivasi berkaitan dengan perilaku dan kinerja, motivasi mencakup pengarahan ke arah tujuan, dan dalam hal mempertimbangkan motivasi, guru perlu memperhatikan faktor-faktor fsiologikal, psikologikal, dan lingkungan sebagai faktor-faktor penting.

\section{Memahami Harga Diri (self-} esteem) :

Menurut Gilmore dalam Akhmad Sudrajad ".....self esteem is a personal judgement of worthiness that is a personal that is expressed in attitude the individual holds toward himself". Pendapat ini menerangkan bahwa harga diri merupakan penilaian individu terhadap kehormatan dirinya, yang diekspresikan melalui sikap terhadap dirinya. Sementara itu, Buss (1973) memberikan pengertian harga diri sebagai penilaian individu terhadap dirinya sendiri, yang sifatnya implisit dan tidak diverbalisasikan. Harga diri adalah penilaian individu terhadap kehormatan diri, melalui sikap terhadap dirinya sendiri yang sifatnya implisit dan tidak diverbalisasikan dan menggambarkan sejauhmana individu tersebut menilai dirinya sebagai orang yang memiliki kemampuan, keberartian, berharga, dan kompeten.

Salah satu komponen konsep diri adalah harga diri, yaitu penilaian individu tentang pencapaian diri dengan menganalisa seberapa jauh perilaku sesuai dengan ideal diri (Keliat, 1999). Sedangkan harga diri rendah adalah menolak dirinya sebagai sesuatu yang berharga dan tidak bertanggungjawab atas kehidupannya sendiri. Jika individu sering gagal maka cenderung harga diri rendah. Harga diri rendah jika kehilangan kasih sayang dan penghargaan orang lain. Harga diri diperoleh dari diri sendiri dan orang lain, aspek utama adalah diterima dan menerima penghargaan dari orang lain. 
Edutech, Tahun 12, Vol.1, No.3, Oktober 2013

Gangguan harga diri rendah lingkungan sosialnya" (Jordan et. al. digambarkan sebagai perasaan yang negatif terhadap diri sendiri, termasuk hilangnya percaya diri dan harga diri, merasa gagal mencapai keinginan, mengkritik diri sendiri, penurunan produktivitas, destruktif yang diarahkan pada orang lain, perasaan tidak mampu, dan mudah tersinggung.

Orang tua dan guru memiliki tanggung jawab besar untuk dapat memenuhi kebutuhan harga diri anak (siswanya), melalui pemberian kasih sayang yang tulus, sehingga anak dapat tumbuh dan berkembang secara wajar dan sehat, yang didalamnya terkandung perasaan harga diri yang stabil dan mantap. Disinilah, tampak arti penting peran orang tua dan guru sebagai fasiltator. Pentingnya pemenuhan kebutuhan harga diri individu, khususnya pada kalangan remaja, terkait erat dengan dampak negatif jika mereka tidak memiliki harga diri yang mantap. Mereka akan mengalami kesulitan dalam menampilkan perilaku sosialnya, merasa inferior dan canggung. Sebaliknya, "jika kebutuhan harga diri mereka dapat terpenuhi secara memadai, kemungkinan mereka akan memperoleh sukses dalam menampilkan perilaku sosialnya, tampil dengan kayakinan diri (self-confidence) dan merasa memiliki nilai dalam 1979). Berikut ada tips dan trik untuk menumbuhkan dan meningkatkan harga diri (versi choose to be happy) :

a. Belajar untuk selalu menghargai diri sendiri, walaupun terkadang orang lain memandang diri anda rendah tapi tetapkan keyakinan anda bahwa andalah yang berhak atas hidup anda dan anda yang paling mengerti diri anda.

b. Belajar untuk menyukai diri sendiri. Menyukai diri sendiri berarti menerima diri apa adanya dan belajar untuk mengembangkan potensi yang dimiliki. Lihat sisi positif dari diri anda, dan yang paling penting adalah bersyukur untuk segala yang kita miliki.

c. Miliki gambar diri yang positif. Hal ini berhubungan dengan penerimaan diri. Gambar diri adalah cara pandang anda terhadap diri anda, yakinkan diri anda kalau anda layak untuk berhasil, anda pantas untuk dicintai dan dihargai, anda adalah pribadi yang spesial. Ingatlah bahwa gambar diri anda mmpengaruhi perilaku anda.

d. Lakukan apa yang anda anggap penting. Walaupun anda merasa anda tidak mampu karena anda malu dan takut, paksakan diri anda untuk melalui proses itu. 
Edutech, Tahun 12, Vol.1, No.3, Oktober 2013

Percayalah bahwa ternyata diri anda mampu untuk melakukannya. yang perlu diingat adalah semakin kita paksakan untuk melalu proses yang tidak enak, semakin anda memperluas daerah teritori kenyamanan anda.

e. Belajar untuk hidup mandiri, tidak tergantung dengan orang lain, sehingga anda tidak rentan terhadap penolakan.

f. Jangan menghubungkan harga diri anda dengan kegagalan atau kesalahan yang anda lakukan. Tanamkan pada diri anda untuk tidak menyerah pada keadaan.

g. Miliki konsep diri yang benar tentang harga diri, bahwa harga diri berasal dari dalam bukan dari luar diri kita, bukan pula terletak pada materi yang kita peroleh, kesuksesan yang kita peroleh karena materi dan kesuksesan hanya menumbuhkan harga diri semu dan tidak dapat bertahan selamanya.

h. Hargai diri sendiri, jangan tolak pujian sederhana yang dikatakan orang mengenai kita. Terima itu dan berpikir lebih maju lagi. Hatihati bila ada kata-kata dibenak anda seperti "aku memang bodoh", " aku memang gak bisa", "ini cuma mimpi, gak mungkin jadi nyata". Kata-kata beracun ini akan merusak harga diri anda yang anda bangun perlahan-lahan.

(Sumber

http://belajarpsikologi.com/carameningkatkan-hargadiri/\#ixzzlivpO5Zyi)

Dalam melakukan penataan lingkungan belajar di kelas, guru melakukan aktivitas pengelolaan kelas (classroom management). Menurut Milan Rianto (2007), pengelolaan kelas merupakan upaya pendidik untuk menciptakan dan mengendalikan kondisi belajar serta memulihkannya apabila terjadi gangguan dan/atau penyimpangan, sehingga proses pembelajaran dapat berlangsung secara optimal. Optimalisasi proses pembelajaran menunjukan bahwa keterlaksanaan serangkaian kegiatan pembelajaran (instructional activities) yang sengaja direkayasa oleh pendidik dapat berlangsung secara efektif dan efisien dalam memfasilitasi peserta didik sampai dapat meraih hasil belajar sesuai harapan. Hal ini dimungkinkan, karena berbagai macam bentuk interaksi yang terbangun memberikan kemudahan bagi peserta didik untuk memperoleh pengalaman belajar (learning experiences) dalam rangka menumbuhkembangkan kemampuannya, yaitu spiritual, mental: 
Edutech, Tahun 12, Vol.1, No.3, Oktober 2013

intelektual, emosional, sosial, dan fisik (indera) atau kognitif, afektif, dan psikomotorik.

Indra Djati Sidi (2005) menegaskan "dalam menata lingkungan belajar di kelas yang menarik minat dan menunjang siswa dalam pembelajaran erat kaitannya dengan keadaan lingkungan fisik kelas, pengaturan ruangan, pengelolaan siswa dan pemanfaatan sumber belajar, pajangan kelas, dan lain sebagainya." Oleh karena itu, secara fisik lingkungan belajar harus menarik dan mampu membangkitkan gairah belajar serta menghadirkan suasana yang nyaman untuk belajar. Kelas harus bersih, tempat duduk harus rapih agar anak bisa melakukan aktivitas belajar dengan bebas. Dinding kelas di cat berwarna sejuk, terpampang gambar-gambar atau foto yang mendukung kegiatan belajar, seperti gambar pahlawan, lambang negara, presiden dan wakil presiden, kebersihan lingkungan, famlet narkoba, dan sebagainya.

\section{Menurut DePorter Bobbi,}

Reardon Mark dan Singer Sarah Nuurie (2001), bahwa lingkungan yang memacu belajar dan daya ingat siswa dapat diperoleh dengan menata : (1) lingkungan sekeliling dalam kelas, (2) Alat bantu, (3) pengaturan tempat duduk, (4) tumbuhan, aroma, hewan peliharaan, dan unsur organik lainnya, dan (5) musik dan belajar. Berdasarkan uraian di atas maka dapat disarikan bahwa lingkungan belajar yang di tata dan dapat memacu belajar serta daya ingat siswa meliputi:

D. SIMPULAN

\section{Beberapa Implikasi Bagi Guru}

a. Guru yang profesional adalah guru yang dapat melaksanakan pembelajaran dengan baik. Mengajar hendaknya diartikan sebagai upaya mengorganisasikan lingkungan belajar agar siswa dapat melakukan tindakan belajar. Dalam mengajar, guru juga harus memperhatikan "rasa kemanusiaan dan kehangatan".

b. Dalam proses pembelajaran, guru perlu melakukan praktik reflektif, melaksanakan pembelajaran yang berpusat pada siswa, merencanakan kurikulum, memahami dan mengembangkan kompetensi guru, mengembangkan profesional guru, membangun komunitas sekolah, memahami kesetaraan, dan memiliki tanggung jawab guru.

c. Guru harus memahami perkembangan belajar anak. Oleh karena itu, guru harus memahami pula teori-teori perkembangan anak, seperti teori perkembangan 
Edutech, Tahun 12, Vol.1, No.3, Oktober 2013

kognitif, teori pengembangan sosial, emosional dan moral. Guru juga harus dapat memotivasi dan mengembangkan harga diri (selfesteem) siswa serta mengatur lingkungan belajar (kelas) dengan baik.

d. Guru merupakan ujung tombak dalam pengembangan kurikulum di sekolah, karena itu ia harus menguasai konsep-konsep kurikulum, bagaimana cara melaksanakan dan mengevaluasi kurikulum. Guru juga harus dapat menterjemahkan kurikulum dalam pembelajaran. Dalam konteks ini, guru dituntut untuk mampu membuat perencanaan pembelajaran, mengorganisasi struktur kelas, melaksanakan dan mengevaluasi pembelajaran

e. Guru harus dapat melaksanakan pembelajaran secara efektif, yang meliputi : berkomunikasi efektif, mengembangkan model pembelajaran efektif, manajemen kelas, menggunakan sumber daya secara kreatif, memahami perbedaan siswa dalam belajar, mengembangkan prinsip nilai dan moral, bekerjasama dengan orang tua siswa, melakukan penilaian dan membuat laporan. f. Guru harus memahami konsepkonsep profesi guru, melakukan setiap tindakannya sesuai dengan kode etik guru, dan bergabung dalam salah satu organisasi profesi guru untuk perlindungannya.

\section{DAFTAR PUSTAKA}

Adrian. (2004) Metode Mengajar Berdasarkan Tipologi Belajar Siswa. [Online] Tersedia: http://www.artikel.us art0565.html.

Arifin, Zainal, (2011) Evaluasi Pembelajaran : Prinsip-TeknikProsedur, Bandung : PT.Remaja Rosdakarya. , (2011) Konsep dan Model Pengembangan Kurikulum, Bandung : PT.Remaja Rosdakarya.

DePorter Bobbi, Reardon Mark \& Singer Sarah-Nuurie (2001) Quantum Teaching (Memperhatikan Quantum Learning Di Ruangruang Kelas), Terjemahan Ary Nilandri, Bandung : Kaifa.

Gibson, James L., John M. Ivancevich dan James H. Donnelly, Jr. (1996) Organisasi, Perilaku, Struktur, Proses, (Alih Bahasa Nunuk Adiarni), Jakarta : Penerbit Binarupa Aksara.

Gomes, Faustino Cardoso, (2001) Manajemen Sumber Daya Manusia, Yogyakarta : Andi Offset.

Hamalik, Oemar, (2001) Proses Belajar Mengajar, Jakarta : Bumi Aksara. 
Hasibuan, Malayu SP. (2003) Organisasi dan Motivasi Dasar Peningkatan Produktivitas, Jakarta : Bumi Aksara.

Indrawijaya, Adam I., (1989) Perilaku Organisasi, Bandung : Sinar Baru.

Mathis, Robert L., and Jackson, John H., (2000) Human Resource Management, New York : SouthWestern College Publishing.

Rianto, Milan (2007) Pengelolaan Kelas Model Pakem, Jakarta : Dirjen PMPTK.

Stamboel, Conny Semiawan, dkk (1992) Pendidikan Ketrampilan Proses, Bagaimana Mengaktifkan Siswa dalam Belajar, Jakarta : PT Gramedia.

Sumantri, Suryana, (2001) Perilaku Organisasi, Bandung : Universitas Padjadjaran.

Usman, Moh. Uzer, (1994) Menjadi Guru Profesional, Bandung : PT Remaja Rosdakarya.

Winardi. (2002) Motivasi dan Pemotivasian dalam Manajemen, Jakarta : PT Raja Grafindo Persada. 